\title{
THE GENUS BALANOPHORA (BALANOPHORACEAE) IN SABAH, MALAYSIA
}

\author{
TODD J. BARKMAN ${ }^{1}$, BELLIA E. EMOI² \& RIMI REPIN²
}

\begin{abstract}
SUMMARY
A total of five species are included in this treatment of Balanophora (Balanophoraceae) including $B$. fungosa subsp. fungosa and B. elongata which are new records for Borneo. All five species occur on Mt Kinabalu. We provide brief descriptions, a key to differentiate all five species, as well as illustrations to assist in their identification.
\end{abstract}

Key words: Balanophora, Borneo, Mt Kinabalu.

\section{INTRODUCTION}

The genus Balanophora J.R. Forst. \& G. Forst. is comprised of holoparasitic flowering plants that commonly parasitize the roots of a wide variety of plant species. The 15 currently recognized Balanophora species are distributed throughout temperate and tropical Asia, ranging at the eastern extreme in Australia to a western limit in Africa (Hansen, 1972). While many species like B. abbreviata Blume are widespread throughout Malesia, others like $B$. wilderi Setch. are more narrowly distributed. Within Balanophora, two subgenera have been delimited (Hansen, 1972). Subgenus Balanophora is comprised of four sections with 4-6-merous male flowers whereas subgenus Balania is comprised of two sections each with 3-merous taxa. Only subgenus Balanophora is found in Sabah and includes species from section Balanophora (B.fungosa), Dibalaniella (B. elongata, B. lowii, and B. papuana), and Alopecosathe (B. reflexa).

Species of Balanophora are among the most bizarre of all flowering plants having yellow, orange, or red inflorescences that emerge from warty tubers that are attached to their host plants. Details of the host-parasite interface of Balanophora have been anatomically described and reveal intimate cellular contact (Hsiao \& Mauseth, 1995). In particular, the presence of a parasite-produced sheath surrounding host vascular tissues that includes transfer cells has a probable role in nutrient absorption (Hsiao \& Mauseth, 1995; Gedalovich-Shedletzky \& Kuijt, 1990). The female flowers in Balanophora are among the most reduced in the angiosperms with more than one million hair-like flowers estimated from a single inflorescence (Hansen, 1972). The male flowers are comprised of fused stamens (synandria) that usually produce white pollen. Pollinators have only been reported for a few species and it appears that these curious flowers may be pollinated by ants, cockroaches, and moths (Kawakita \& Kato, 2002).

1) Department of Biological Sciences, Western Michigan University, Kalamazoo, MI 49008, USA.

2) Research and Education Division, Sabah Parks, P.O. Box 10626, 88806 Kota Kinabalu, Sabah, Malaysia. 
The measurements and descriptions made here were based on fresh, dried, and spirit material. One of the most important characters for identification of Balanophora species is leaf arrangement and number. Although it is sometimes challenging to determine leaf arrangement on dried material, pickled specimens are more straightforward to assess. Identification of species is substantially simpler for male specimens, which have more distinguishable characters than female plants. Useful male characteristics include flower symmetry, pedicel length, and subtending bract features. However, many characters of Balanophora specimens may be variable including the overall plant height, number of leaves, the shape of bracts that subtend the male flowers, and male flower size. The abundant variation in morphology of many Balanophora species has historically led to a proliferation of regional names (Hansen, 1972, 1999). The purpose of this study is to report two new Balanophora records for Sabah, Borneo and provide a key to differentiate the five species that are now known to occur there. Although previously treated in 1972, a new systematic treatment coupled with phylogenetic work would enhance our understanding of species boundaries and the morphological diversity that exists within the genus.

\section{ARTIFICIAL KEY FOR SABAH SPECIMENS}

1a. Plants monoecious with male and female flowers in the same inflorescence .... 2. B. fungosa subsp. fungosa

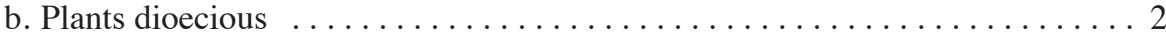

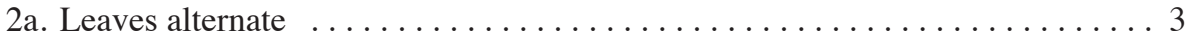

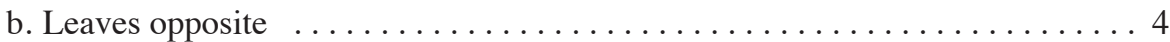

3a. Leaves not enveloping inflorescence at anthesis; male synandria strongly reflexed at maturity with pedicels normally $>10 \mathrm{~mm}$ long; plants usually bright red, often with a rather strong odor $\ldots \ldots \ldots \ldots \ldots \ldots \ldots \ldots \ldots \ldots \ldots \ldots \ldots$. B. reflexa

b. Leaves enclosing inflorescence to various extents at anthesis; male synandria only slightly reflexed at maturity, pedicels normally less than $10 \mathrm{~mm}$ long; plants yellow-orange to orange-red, without odor . . . . . . . elongata

4a. Leaves 10-14, small at the base of the inflorescence and larger at the apex, completely enclosing the mature inflorescence; tubers globose, solitary . . 3. B. lowii

b. Leaves 4-6, approximately of the same size, not completely enclosing the mature inflorescence; tubers elongate and often branched

4. B. papuana

\section{SPECIES DESCRIPTIONS}

\section{Balanophora elongata Blume - Fig. 1}

Balanophora elongata Blume (1827) 87; Hansen (1972) 114; (1976) 797.

Dioecious herb, yellow-orange to orange-red, overall length from the tip of the inflorescence to the point of tuber attachment to host root 5-14 cm. Tubers singular or more usually branched, rather elongate, $1-3$ by $4-7 \mathrm{~cm}$, surface granular with scattered, raised stellate warts. Leaves $8-10$, alternate, imbricate, obovate, modestly increasing in size up the stem, $1-2.25$ by $3-4 \mathrm{~cm}$, obtuse, concave, usually partly concealing the inflorescence at maturity, leaves from pickled material with 7-9 main veins that only 

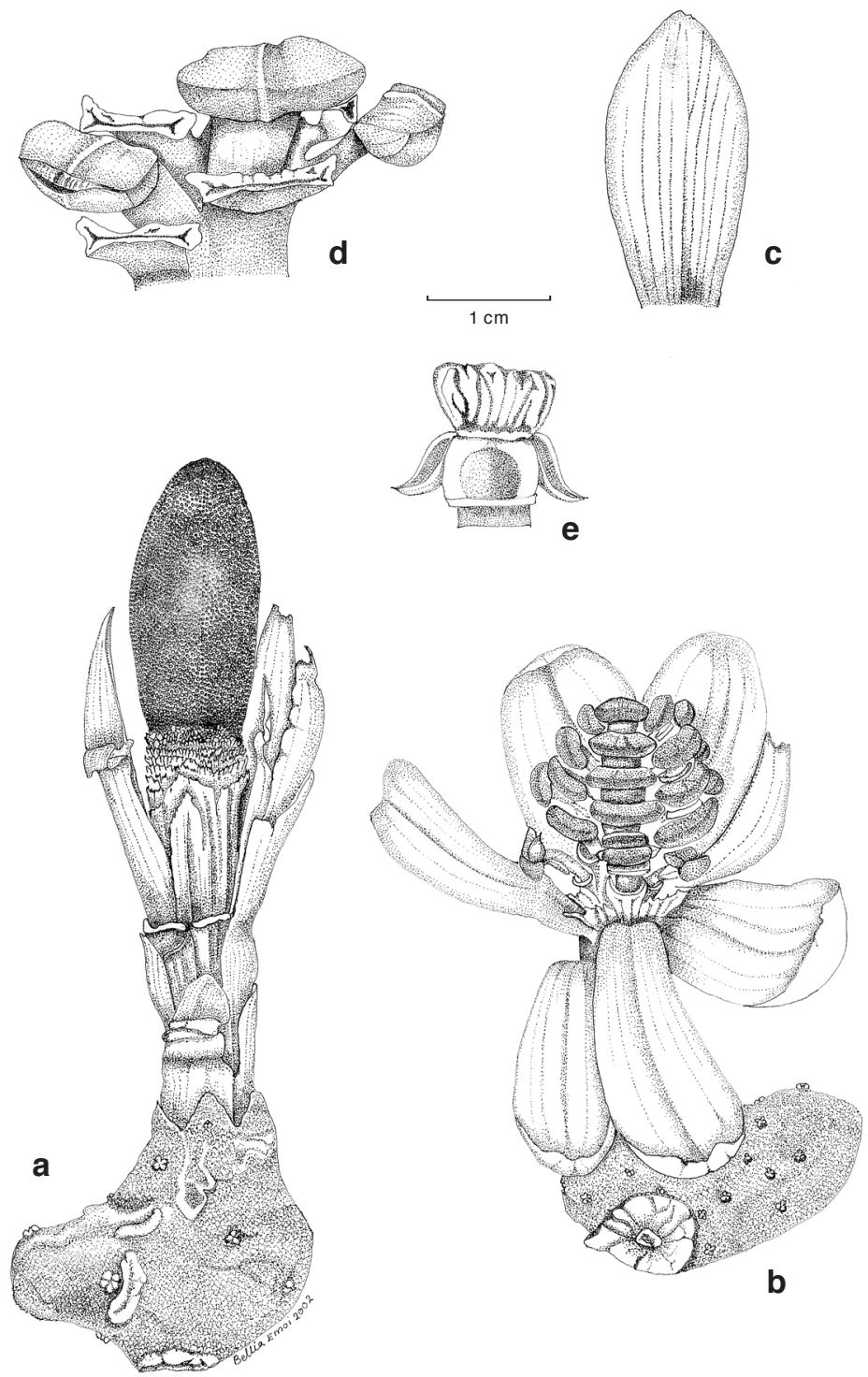

Fig. 1. Balanophora elongata Blume. a. Female plant (leaves crumpled due to thick moss mat overlaying plant during development); b. male plant with leaves opened to reveal inflorescence; $c$. leaf showing venation pattern; d. male flower buds with subtending bracts; e. male flower at anthesis (all from $S N P$ 17756).

branch occasionally. Male flowers reflexed near synandrium at maturity, strongly bilaterally symmetrical, subtended by a rather tall (3-5 mm), stout, fleshy, wedge-shaped (cuneate), flat-topped (truncate), bract (5-9 mm wide at apex); pedicels up to $10 \mathrm{~mm}$ long; flowers mostly 4-merous (but occasionally appearing 6-merous or more because 
of the splitting of the wide median tepals), median tepals squarish blunt with a flat apex, 6-13 by $3-4 \mathrm{~mm}$; lateral tepals acute, more or less triangular, 2 by $4 \mathrm{~mm}$; synandrium strongly reniform; anther stalk up to $0.5 \mathrm{~mm}$ long, if present; anthers numerous, more or less vertically oriented, pollen white when shed. Female inflorescence $1.5-3$ by $2-5 \mathrm{~cm}$, elongate ovoid to obovoid.

Distribution - Peninsular Malaysia, Sumatra, Java, Borneo.

Ecology - The specimens studied from Borneo indicate that B. elongata is distributed at relatively high elevations on Mt Kinabalu and Mt Tembuyuken. On Mt Kinabalu it has been collected between 1900 and $2500 \mathrm{~m}$ and on Mt Tembuyuken it was collected near the summit (c. $2400 \mathrm{~m}$ ). It is found parasitizing hosts growing on both ultramafic and non-ultramafic sites. At times, $B$. elongata grows on roots deeply embedded in moss making it appear that the individual is short with only a few leaves.

Note - Balanophora elongata from Mt Kinabalu was pictured in Sato (1991: 95) but was incorrectly identified as $B$. reflexa. The large cuneate flat-topped bracts are distinctive for this species and are diagnostic alone if male specimens are available. In pickled material, the broken or cut tubers appear whitish in cross section revealing a wax that is produced by this species (Backer \& Bakhuizen van den Brink, 1965). This species is the most yellowish of all balanophoras on Mt Kinabalu which is discernable even on some herbarium specimens. Balanophora elongata was previously known from Sumatra, Java, and Peninsular Malaysia (Stone, 1979); however, like B. fungosa, has escaped recognition in Borneo in spite of years of intense general collecting, particularly on Mt Kinabalu. It should be noted that although the Sabah material is mostly within the range of size noted for B. elongata (Hansen, 1972), there are several specimens from high elevations on Mt Kinabalu with male flowers far exceeding previous measurements reported for this species.

\section{Balanophora fungosa J.R. Forst. \& G. Forst. subsp. fungosa - Fig. 2}

Balanophora fungosa J.R. Forst. \& G. Forst. (1776) 99, t. 50; subsp. fungosa, Hansen (1972) 98; (1976) 794.

Monoecious herb, red to reddish brown with pink tinges, overall length from the tip of inflorescence to point of tuber attachment to host root 4-5.5 cm. Tubers branched or singular, globose up to 2 by $1.5-2 \mathrm{~cm}$, surface granular covered by stellate warts. Leaves 14-20, opposite, decussate, ovate, increasing in size from the base to tip of stem, 1-2 by $1-3 \mathrm{~cm}$, obtuse, concave, completely concealing the mature inflorescence, 5 or 6 highly branched veins observable in pickled material. Male flowers 3-10 at the base of the inflorescence, subtended by a short (1-2 mm), somewhat fleshy, V-shaped bract; pedicels up to $5 \mathrm{~mm}$ long; individual flowers 4-6-merous, more or less bilaterally symmetrical, median tepals $3-4$ by $3-4 \mathrm{~mm}$, ovate, obtuse; lateral tepals $1-2$ by $3-4$ $\mathrm{mm}$, lanceolate, acute; synandrium ovoid to reniform sometimes laterally compressed; anther stalk up to $1 \mathrm{~mm}$ long; anthers numerous, more or less vertically oriented, pollen yellowish before dehiscence, white when shed. Female part of inflorescence $1-1.7$ by $0.8-1.8 \mathrm{~cm}$, obovoid to globose.

Distribution - Burma, Java, Borneo, Philippines, Ryu Kyu Is., Celebes, Micronesia, N Australia, New Guinea, Solomon Is., New Caledonia, New Hebrides, and Fiji. 


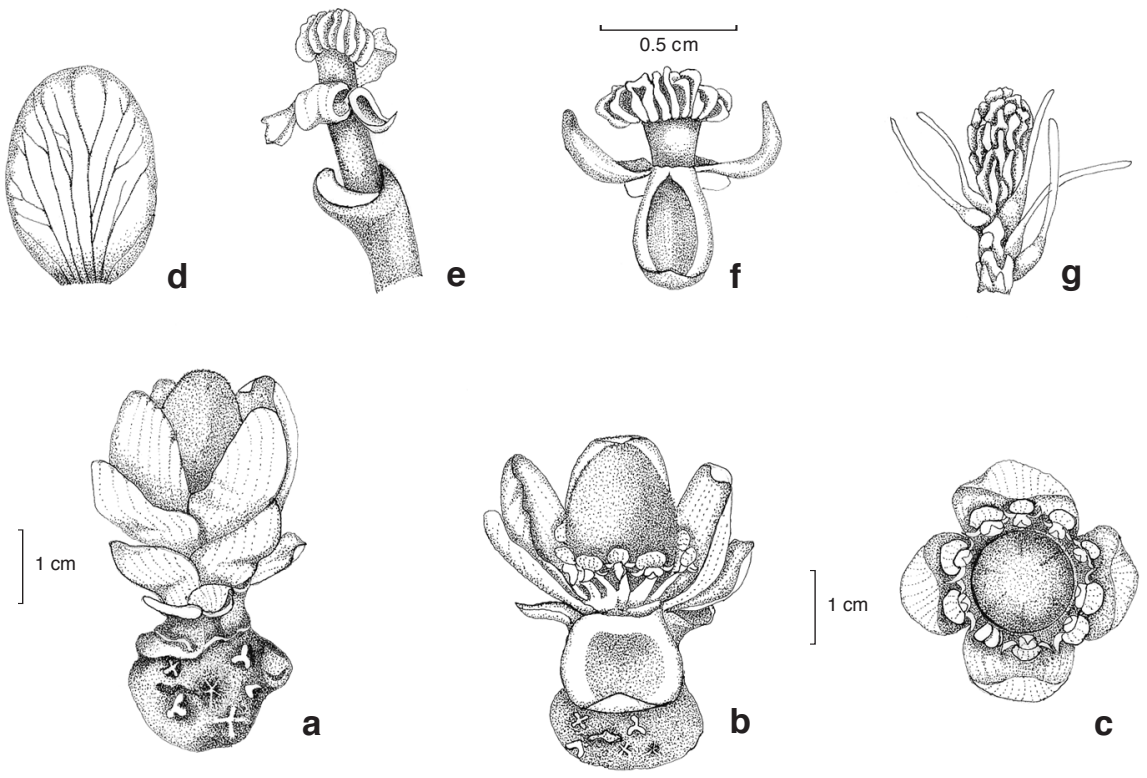

Fig. 2. Balanophora fungosa J.R. Forst. \& G. Forst. subsp. fungosa. a. Whole plant with leaves in natural position; b. whole plant with leaves opened to reveal inflorescence; c. whole plant top view; d. leaf showing venation pattern; e. male flower lateral view; f. male flower abaxial view; g. spadicle with female flowers (all from SNP 17759).

Ecology - In Borneo, this species is known from only two localities on Mt Kinabalu: Marai parai and Mesilau Falls. These sites, distributed between 1600 and $1900 \mathrm{~m}$, are significantly higher than the $0-1000 \mathrm{~m}$ reported by Hansen (1972). Our recent trip to the Mesilau substation of Kinabalu Park revealed Hedyotis spec. as the host upon which $B$. fungosa forms rather large colonies. This species is likely more widespread in Borneo because there is abundant comparable habitat elsewhere. It is surprising that B. fungosa is not more common in Borneo because it is widespread throughout the rest of Malesia (see distribution map in Hansen 1972 and 1976).

Note - The dimensions of B. fungosa subsp. fungosa collected from Mt Kinabalu are at the small end of the range given for this taxon (Hansen, 1972). In addition, the plants are dark red to reddish brown, unlike the yellowish color previously reported. Further differences include the opposite, decussate leaves that Hansen (1972) reports as rarely occurring and the unequal synandrium tepals. Aside from these differences, the Bornean material is typical for $B$. fungosa subsp. fungosa and it cannot be referred to any other $B$. fungosa subspecies because it is monoecious. We suggest that the more diminutive size is due to the higher elevations from which our material was collected. Although leaf arrangement and floral symmetry are characters typically used to define many Balanophora species we reserve the assignment of a new name to this Kinabalu material pending further studies. 

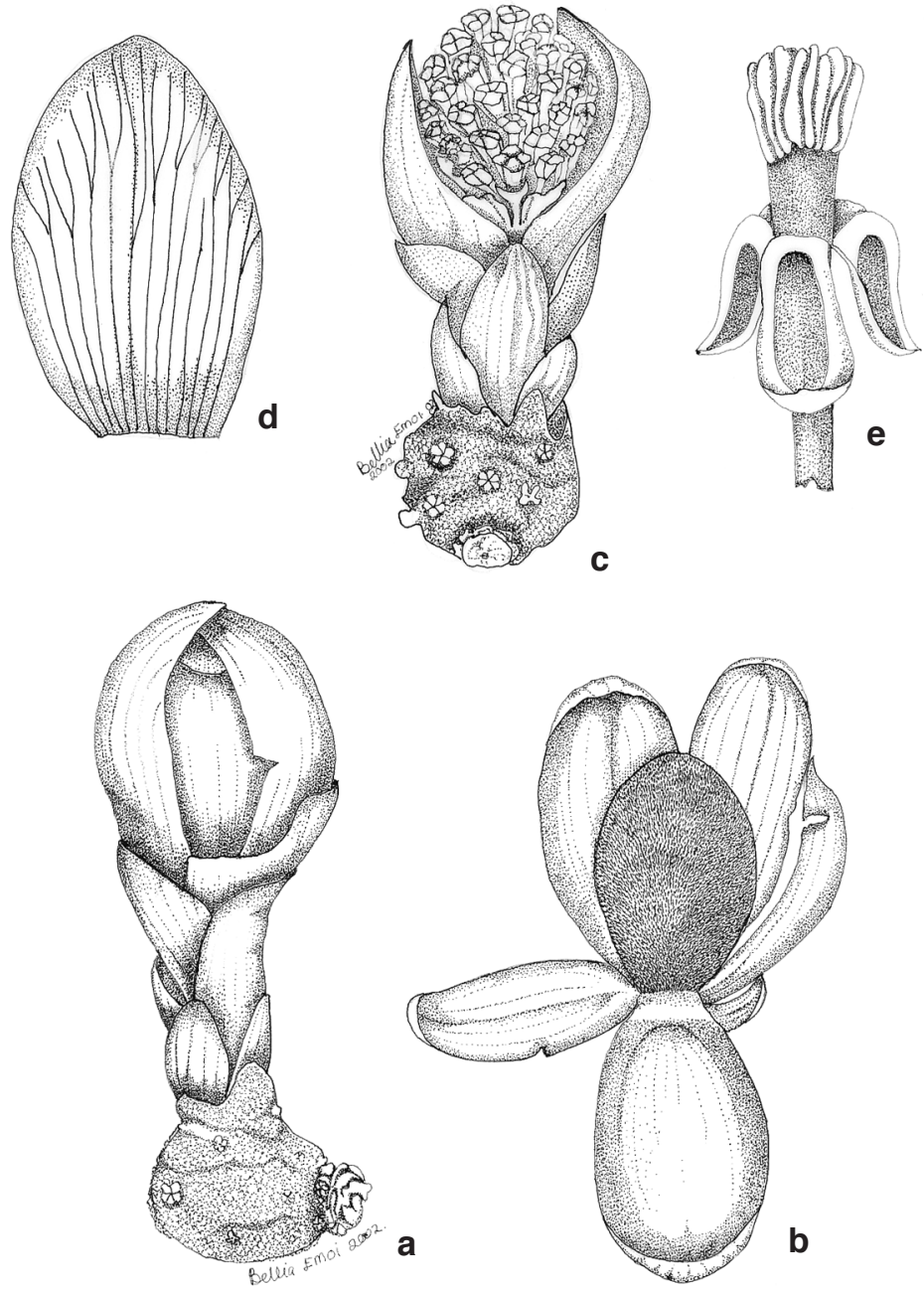

Fig. 3. Balanophora lowii Hook.f. a. Female plant with leaves in natural position; b. female plant with leaves opened to reveal inflorescence; c. male plant with some leaves removed to reveal immature inflorescence; d. leaf showing venation pattern; e. male flower at anthesis (all from SNP 17757).

\section{Balanophora lowii Hook.f. - Fig. 3}

Balanophora lowii Hook.f. (1859) 426; Hansen (1972) 127; (1976) 800; Beaman et al. (2001) 146.

Dioecious herb, red to reddish brown, overall length from the tip of the inflorescence to the point of tuber attachment to host root (3-)5-10 cm. Tubers singular, globose, 1.7-2.5 by $1.5-2.5 \mathrm{~cm}$, surface granular with scattered stellate warts. Leaves 10-14, opposite and decussate, ovate, increasing in size up the stem, 1-3 by $1-5 \mathrm{~cm}$, obtuse, concave, usually completely concealing the inflorescence at maturity, 10-14 veins observable 
in pickled specimens that nearly all branch at the apex. Male flowers numerous, erect (not reflexed) at maturity, more or less actinomorphic (although some flowers clearly zygomorphic), subtending bract up to 3 by $2 \mathrm{~mm}$; pedicels $5-7 \mathrm{~mm}$ long; individual flowers 4- or 5-merous, tepals $2-3$ by $3-5 \mathrm{~mm}$, ovate to lanceolate, acute to obtuse or truncate; synandrium ovoid or slightly cuneate due to lateral compression; anther stalk 1-1.5 mm long; anthers numerous, more or less vertically oriented, pollen white when shed. Female inflorescence $1.75-2.5$ by $2-3.5 \mathrm{~cm}$, ovoid to globose.

Distribution - Borneo.

Ecology - Aside from the citation in Hansen (1972) of Burtt \& Woods' collection of B. lowii from Mt Berumput, Sarawak, this species is otherwise only known from Mt Kinabalu, Sabah where it tends to be restricted to higher elevations (1550-3220 $\mathrm{m}$ ). Although it may rarely be found below $2000 \mathrm{~m}$, B. lowii appears to be much more common at high elevations above $2600 \mathrm{~m}$.

Note - Balanophora lowii and B. fungosa subsp. fungosa are the only Bornean species with leaves that increase in size from the base toward the tip of the inflorescence and each usually has solitary globose tubers. However, B. fungosa subsp. fungosa is easily distinguishable by its monoecious nature. Because the inflorescences of $B$. lowi are completely concealed at anthesis, it is unclear how pollination can occur.

\section{Balanophora papuana Schltr. - Fig. 4}

Balanophora papuana Schltr. (1913) 68; Hansen (1972) 121; (1976) 798; Beaman et al. (2001) 146.

Dioecious herb, color not apparent in our pickled specimen but inflorescences are typically bright red to orange-yellow or yellow, overall length from the tip of the inflorescence to the point of tuber attachment to host root 6-12 cm. Tubers somewhat branched, individual tubers elongate, $2.5-4.5$ by $3-5 \mathrm{~cm}$, surface granular, sometimes with stellate warts. Leaves 4 or 6 , opposite and decussate, ovate (occasionally strongly spathulate), all of the same size on a single plant, $1-2.5$ by $2-3 \mathrm{~cm}$, obtuse, concave, not concealing the inflorescence at maturity, margins slightly irregularly erose or toothed near the apex, 7 or 8 veins, several of which are branched. Male flowers numerous, subtended by small, rather inconspicuous tooth-like bracts; pedicels up to $4 \mathrm{~mm}$ long (although probably longer in mature specimens; ours was immature); individual flowers 4-6-merous, tepals quite irregular, with median tepals truncate, $3-5$ by $4-5 \mathrm{~mm}$, conspicuously larger than the acute lateral tepals that measure 2 by 3-4 mm; synandrium obconical, somewhat laterally compressed; anther stalk up to $0.5 \mathrm{~mm}$ long; anthers numerous, vertically oriented. Female inflorescence $2-3$ by $2-3$ $\mathrm{cm}$, ovoid-obovoid to globose.

Distribution - Widespread throughout the Malesian region.

Ecology - Lower to mid montane forest.

Note - Although we have only studied a single collection from Sabah, both male and female plants were available. This species appears relatively simple to identify because of the opposite and decussate leaves that are few in number (4 or 6). However, it should be noted that in female specimens with 6 leaves, the uppermost pair may be subopposite making it potentially mistaken as B. reflexa. Venation of leaves helps to distinguish this species from B. reflexa if spirit material is available. 

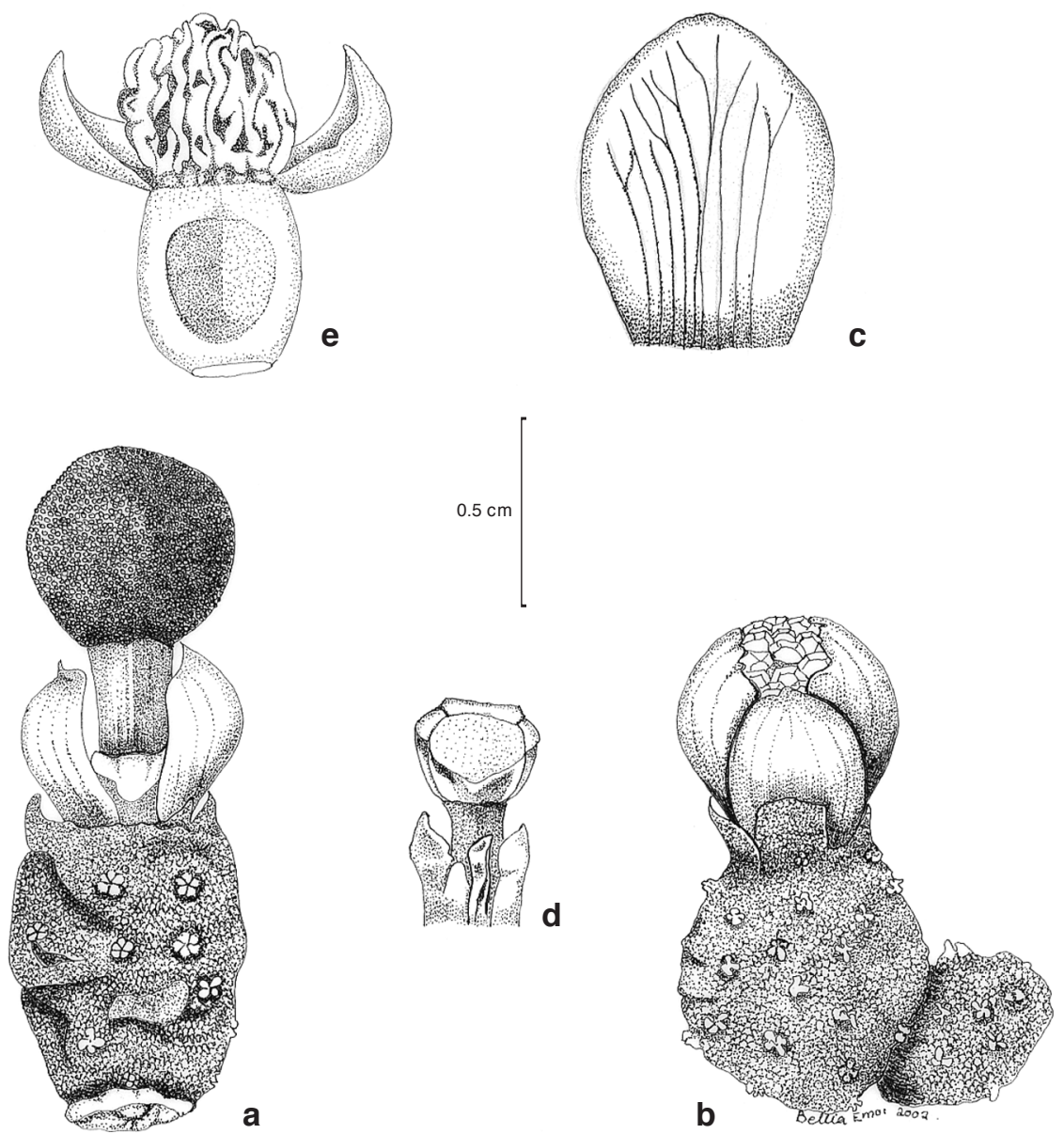

Fig. 4. Balanophora papuana Schltr. a. Female plant at maturity; b. immature male plant; c. leaf showing venation pattern; d. male flower bud with rudimentary bract; e. male flower at anthesis (all from $S N P$ 1767).

\section{Balanophora reflexa Becc. - Fig. 5}

Balanophora reflexa Becc. (1868) 198; Hansen (1972) 130; (1976) 800; Beaman et al. (2001) 146.

Dioecious herb, orange-red to reddish brown, overall length from the tip of the inflorescence to the point of tuber attachment to host root 4-14 cm. Tubers singular or branched, elongate, obovoid, $1.5-4$ by $2-7 \mathrm{~cm}$, surface granular, covered by stellate warts. Leaves 6-8, alternate, linear, concave, all of nearly the same size, $0.5-1.6$ by $1-3.5 \mathrm{~cm}$, obtuse, usually more or less strongly reflexed, completely revealing the inflorescence at maturity, 4-5(-8) veins observable in pickled specimens, veins unbranched (rarely branched near apex). Male flowers numerous and strongly reflexed at anthesis, flattened, subtended by a short, somewhat fleshy, V-shaped, 2-toothed bract; pedicels $0.8-2 \mathrm{~cm}$ long; individual flowers 4-merous, median tepals ovate, 


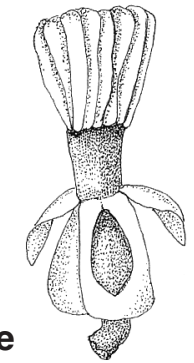

C
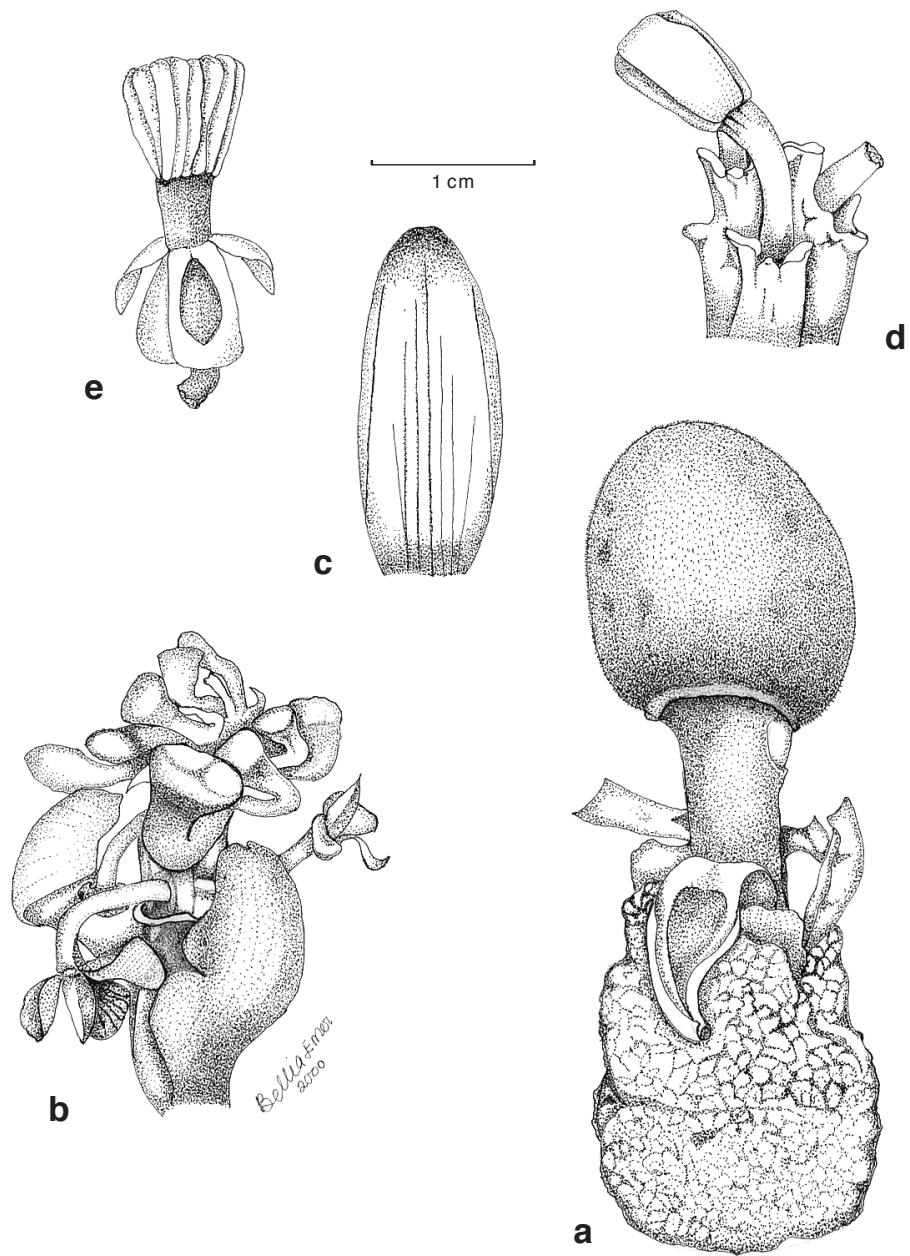

Fig. 5. Balanophora reflexa Becc. a. Female plant; b. male inflorescence; c. leaf showing venation pattern; d. male flower in bud showing subtending bracts; e. male flower at anthesis (all from SNP 17758).

obtuse to truncate, $0.3-1$ by $0.5-1.1 \mathrm{~cm}$; lateral tepals lanceolate, acute, 0.3 by $0.5-1$ $\mathrm{cm}$; synandrium ovoid to cuneiform, strongly laterally compressed; anther stalk 1-3 mm long; anthers numerous, more or less vertically oriented, pollen white when shed. Female inflorescence $1-2.5$ by $1-3 \mathrm{~cm}$, ovoid to obovoid or globose.

Distribution - Borneo and Peninsular Malaysia.

Ecology - The elevational range of this taxon, which is probably the most common Balanophora species in Sabah, is between 500 and $2800 \mathrm{~m}$ with the majority of specimens collected at c. $1500 \mathrm{~m}$.

Note - This is the only species with a noticeably strong odor, which is reminiscent of pandan leaves (Pandanus spec.) which are commonly used to flavor many foods in Malaysia. 
With the addition of $B$. fungosa subsp. fungosa and B. elongata, the total number of species of Balanophoraceae on Mt Kinabalu increases from 3 (Beaman et al., 2001) to 5 . There may be other new species or records from Sabah such as B. abbreviata (which is widespread in Malesia) and B. latisepala (Tiegh.) Lecomte (which is known from Sarawak (Hansen, 1972)) that await discovery.

\section{ACKNOWLEDGEMENTS}

We would like to thank John H. Beaman, Roland Eberwein, and F. Adema for commenting on earlier versions of this manuscript, Victor Siam and Gusili Johalin for assisting with fieldwork, and John Sugau for processing loans from SAN.

\section{REFERENCES}

Backer, C.A. \& R.C. Bakhuizen van den Brink Jr. 1965. Balanophoraceae. Fl. Java II: 78-80.

Beaman, J.H., C. Anderson \& R.S. Beaman. 2001. The Plants of Mount Kinabalu. 4. Dicotyledon families Acanthaceae to Lythraceae. Natural History Publications (Borneo) Sdn. Bhd. Kota Kinabalu, in association with The Royal Botanic Gardens, Kew.

Beccari, O. 1868. Descrizione di tre nuove specie di pianti Bornensi. Atti Soc. Ital. Sci. Nat. 11: 197-199.

Blume, C.L. 1827. Enumeratio Plantarum Javae 1. Van Leeuwen, Leiden.

Forster, J.R. \& G. Forster. 1776. Characteres Generum Plantarum, ed. 2. White, Cadell \& Elmsley, London.

Gedalovich-Shedletzky, E. \& J. Kuijt. 1990. An ultrastructural study of the tuber strands of Balanophora (Balanophoraceae). Canad. J. Bot. 68: 1271-1279.

Hansen, B. 1972. The genus Balanophora J.R. and G. Forster. A taxonomic monograph. Dansk Bot. Ark. 28: 1-188. Kobenhavn.

Hansen, B. 1976. Balanophoraceae. Fl. Males. I, 7: 783-805.

Hansen, B. 1999. Balanophora species published 1971-1998, mostly from China and Japan. Nord. J. Bot. 19: 641-642.

Hooker, J.D. 1859. On a new genus of Balanophorae from New Zealand and two new species of Balanophora. Trans. Linn. Soc. London 22: 415-427.

Hsiao, S.-C. \& J.D. Mauseth. 1995. Composite bundles, the host/parasite interface in the holoparasitic angiosperms Langsdorffia and Balanophora (Balanophoraceae). Amer. J. Bot. 82: 81-91.

Kawakita, A. \& M. Kato. 2002. Floral biology and unique pollination system of root holoparasites, Balanophora kuroiwai and B. tobiracola (Balanophoraceae). Amer. J. Bot. 89: 1164-1170.

Sato, T. 1991. Flowers and plants of Mount Kinabalu. Takashi Sato, Toyama, Japan.

Schlechter, R. 1913. Eine neue Balanophoracee Papuasiens. Bot. Jahrb. Syst. 50: 68, 69.

Stone, B.C. 1979. Balanophora elongata (Balanophoraceae) new to the Malay Peninsula. Malayan Nat. J. 33: 429-432.

\section{IDENTIFICATION LIST}

Following each collection number is the numerical reference assigned to the taxa as they appear in the text.

Barkman 177: 4; 203: 4.

RSNB 114: 2; 953: 4; 1595: 2; 1990: 2; 4140: 4.

Sabah Parks 917: 4; 1009: 2; 1162: 2; 1163: 2; 1249: 4; 1767: 5; 2121: 4; 2156: 2; 2364: 1; 2381: 4; 2407: 4 ; 2458: $3 ; 2911: 4 ; 3067: 3 ; 3080: 2 ; 3349: 3 ; 3871: 2 ; 4505: 3 ; 4506: 3 ; 5361: 4 ; 5392: 4$; 5549: 4; 5643: 2; 8093: 2; 9292: 1; 9615: 2; 15558: 2; 15559: 2; 17756: 3; 17757: 4; 17758: 2; 17759: 1 - SAN 29209: 4; 42737: 2 - Stevens et al. 607: 2 - Surunda 34: 2. 